\title{
Silvopastoral Systems and Costa Rica's Low Carbon Livestock Strategy: An Informed Opinion
}

\section{Los sistemas silvopastorales y la estrategia ganadera de bajas emisiones de carbono de Costa Rica: Una opinión informada}

DOI: $10.53499 /$ sfjeasv1n3-002

Received in: March 1st, 2020.

Accepted in: June 30th, 2020.

\author{
Ricardo O. Russo \\ Ph.D. (Forestry), Yale University, USA; M.Sc. Natural Resources, Agroforestry, University of Costa Rica. \\ Institution: University of Costa Rica, "Alfredo Volio Mata" Experiment Station. \\ Dirección: El Alto, Ochomogo, Costa Rica \\ E-mail: ricardo.russo@ucr.ac.cr
}

\begin{abstract}
The objective of this opinion is to reflect the role of silvopastoral systems (SPS) in Costa Rica's Low Carbon Livestock Strategy (EGBC, for its acronym in Spanish), and how these sustainable and extensive integrated livestock production function as a model, and how the woody component is integrated in the system, contributing to the reduction of greenhouse gases favoring the mitigation of climate change. Applying relevance to the purpose, this revision refers to the integration of forestry activity in livestock production, as a viable alternative of its production system. Based on SPS criteria from which a tree component (natural or established) is associated with an herbaceous community (natural or improved pastures) and a farming component (livestock) in the same site, where biological interactions exist among components, and land use is maximized. This essay also clarifies how SPS are grouped striving to be fair-minded in evaluating the economic, productive, social, and environmental points of view, and the effects of the interaction among its components. Therefore, this analysis applies significance to the interpretation of the SPS relation among biology, society, and culture, and its role in Costa Rica's Low Carbon Livestock Strategy.
\end{abstract}

Key words: Climate change, livestock farming, low carbon strategy, silvopastoral systems.

\section{RESUMEN}

El objetivo de este dictamen es reflejar el papel de los sistemas silvopastoriles (SPS) en la Estrategia de Ganadería Baja en Carbono (EGBC) de Costa Rica, y cómo funcionan como modelo estas producciones ganaderas integradas, sostenibles y extensivas, y cómo se integra el componente leñoso en el sistema, contribuyendo a la reducción de gases de efecto invernadero favoreciendo la mitigación del cambio climático. Aplicando la relevancia al propósito, esta revisión se refiere a la integración de la actividad forestal en la producción ganadera, como una alternativa viable de su sistema de producción. Con base en los criterios de SPS a partir de los cuales se asocia un componente arbóreo (natural o establecido) con una comunidad herbácea (pastos naturales o mejorados) y un componente agrícola (ganadería) en un mismo sitio, donde existen interacciones biológicas entre los componentes, y se maximiza el uso de la tierra. Este ensayo también aclara cómo se agrupan los SPS tratando de ser justos en la evaluación de los puntos de vista económico, productivo, social y ambiental, y los efectos de la interacción entre sus componentes. Por lo tanto, este análisis aplica la importancia de la interpretación de la relación de los SPS entre la biología, la sociedad y la cultura, y su papel en la Estrategia de Ganadería Baja en Carbono de Costa Rica.

Palabras clave: Cambio climático, ganadería, estrategia baja en carbono, sistemas silvopastoriles. 


\section{INTRODUCTION}

Traditional livestock farming with models, based on cultivated pastures or feedlot fed concentrates, generates enormous pressures on natural resources, but at the same time it is the means of livelihood for many families. With this scenario, the vulnerability of the livestock production system is increased by the presence of extreme climatic events expressed in increased temperatures in the low plain areas and abundant rainfall in the foothills, which affects the low availability of food in critical seasons (Guerrero et al., 2019).

In general, it is accepted that SPS and the livestock production-complementary forestry activities constitute a viable production alternative. The products and ecosystem services provided by trees and the tree component allow to obtain short-, medium- and long-term benefits. It is assumed that each production unit works as a true integrated system, with the adequate interrelation of each of its components animals, forestry, and pastures, complemented with good management, better yields and the sustainability of production can be reached, which should be shown in an increase of productivity per hectare (Ibrahim et al., 2003; Russo, 1996).

\section{SOME CONCEPTS HANDLED IN THE LIVESTOCK FARMING COMMUNITY}

The objective of this analysis was to reflect upon those livestock production models, in which the woody component is integrated, contributing to the reduction of greenhouse gases, and favoring the mitigation of the climate change (Suber et al, 2019). For such purpose, a series of concepts and aspects of the integration of the forestry activity in livestock production are managed by the livestock farming community (Hernández et al., 2000).

Behind the notion of SPS for lie differing conceptions: 1) SPS with a forestry approach (Including grazing of tree plantations, natural forests or orchards); and 2) SPS with a livestock production approach (Including silvopastures, isolated trees in paddocks, living fences, integrated mixed systems, forage banks, agroforestry practices in livestock production, intensive silvopastoral systems specialized in animal production). These underlying conceptions determine the different discourses and practices about SPS (Russo, 2015). This seems obvious. Nevertheless, though they form the basis of any decision regarding management action, these conceptions not always are clarified. Emphasizing the urgency of acting, there is even a tendency to reduce to a minimum any useless discussion on this topic. To move forward in a pertinent manner, it is of primary importance to reveal and confront the underlying conceptions that make up the construct "silvopastoral system", whether the perspective of "environmentally friendly production" is fully adopted or considered from a critical point of view. This clarification process concerns both our own representations and those expressed in the practices and other discourses. 
In a global sense, stopping deforestation and forest degradation was a fundamental point of the United Nations Conference on Climate Change in Bonn, COP23. This not only promotes the restoration of forests and rural landscapes, but also the application of methods that make their conservation compatible with the sustainable development of societies (Botero \& Russo, 2016). However, to increase productivity in livestock systems, and restore landscapes dominated by livestock, it is necessary to address the problem of pasture degradation (Pezo, 2016; Pezo et al, 2018). Although, opportunities to recover pastures exist and are achieved using good management practices and silvopastoral options, in which the Tropical Agricultural Research and Higher Education Center (CATIE, for its Spanish acronym), in Turrialba, Costa Rica has been working and developing for the last 20 years (Danilo Pezo, personal communication).

Furthermore, Costa Rica has placed a strong emphasis on its climate change mitigation policies, the country has implemented a Low Carbon Livestock Strategy (EGBC). within the framework of the National Decarbonization Plan of the Economy. Livestock has been positioned as one significant economic activity and, therefore, also as one of the sectors with greenhouse gas (GHG) emissions. This sector is responsible for approximately $23 \%$ of the country's gross emissions (CR-MINAE, 2015).

The work experience in the region highlights some aspects to consider to Costa Rica: For instance, the adaptation of the agricultural sector requires work to articulate public and private efforts, which include actions from on the farms even in production support services. In this sense it is important the support that can be given by public institutions and the private sector to local plans and agendas for the development of strategies for adaptation (Pezo, 2016). Considering that the public sector has established policies and mechanisms that provide a basis for adaptation to climate change of national agriculture, such as the National Policy for the Agrifood Sector and the Rural Development 2010-2021 (CR-SEPSA, 2011) and Agro-environmental and Climate Change Sectorial Articulation Strategy action plans for the agricultural and security food sector, the space for possible synergies between mitigation and adaptation agendas is clear (CR-SEPSA, 2016).

Another biophysical aspect that is conceptualized by farmer is that the use of SPS reduces soil erosion, increases the retention and infiltration of water in the soil and favors the growth of associated pastures when the density of trees in the pasture is adequate (Botero \& Russo, 2016).

\section{THE CURRENT SITUATION}

In Costa Rica, bovine production is the most spread animal production activity, it contributes approximately $20 \%$ of the country's emissions ( 2.3 million tons annual $\mathrm{CO}_{2}$ e) by their production processes. According to estimates made by the National Institute of Innovation and Transfer in 
Agricultural Technology (INTA), organ attached to the MAG, the main source of emission is enteric fermentation and not deforestation. By on the contrary, it is observed that the farmer dedicates time to protect forests, biodiversity and water on their farms (Abarca, 2016). Currently, about 1,000 farms are implementing measures to mitigate and adapt to climate change. By 2022, the goal is for 1,773 farms to not only have reduced their emissions (a cut of 39,000 tons of $\mathrm{CO}_{2} \mathrm{e}$ is expected) and increased their resilience, but also be more profitable economically. By 2034 it is expected to have $70 \%$ of the farms operating under these sustainability criteria. The objective of the Livestock NAMA is to ensure that the farms generate the highest possible economic performance per unit of area, betting on efficiency and sustainability. All this without extending the agricultural frontier, rather trying to recover the forest cover through living fences and wooded pastures (currently there are 20 million trees scattered in the area). In this sense, and according to calculations made by the National Forestry Financing Fund (FONAFIFO) in 2015 when the NAMA was designed, the country has a forestry recovery potential of 620,000 hectares just by combining agricultural activity with trees (CR-MINAE-MAG, 2015; CF-MAG, 2018).

The information emanating from the Ministry of Agriculture and Livestock and the National Institute for Innovation and Transfer of Agricultural Technology (INTA) indicates that Costa Rican farmers have more than 20 million trees scattered in pastures, that the measures give an economic return of almost the $11 \%$, and that in addition the rancher takes care of $18 \%$ of the national territory in forests, outside those protected by the state.

\section{FINAL CONSIDERATIONS}

I really like the phrase used by the country's authorities that "The ability to fix carbon rests on the shoulders of livestock farms". In Costa Rica, livestock has been positioned as one of the main economic activities and, therefore, also as one of the sectors with the highest greenhouse gas (GHG) intensity. This sector is responsible for approximately $23 \%$ of the country's gross emissions. In 2012, and according to the inventory of Greenhouse Gases (GHG) carried out by the National Meteorological Institute (IMN), its carbon footprint was 2,084 gigagrams of carbon dioxide equivalent $\left(\mathrm{CO}_{2} \mathrm{e}\right)$ (CR-IMN-MAG, 2019). However, experts say that livestock in Costa Rica captures more greenhouse gases than it emits (El País, 2021).

Farmers have been implementing actions since 2014, even before the Paris Agreement was signed. Currently they hope to more: in 2030, for example, $70 \%$ of the herd will be under low-emission production systems and $60 \%$ of the area dedicated to the activity will incorporate adaptation and resilience measures. This is stated in the Nationally Determined Contribution (NDC) that was presented to the United Nations in December 2020. This NDC brings together the climate goals to which the country commits itself within 
the framework of the Paris Agreement, which they should be implemented in the next 10 years (CRMINAE, 2015; 2020).

According to data from the Directorate of Climate Change (DCC), livestock occupies 1.4 million hectares of the national territory, of which one million hectares correspond to pastures. The challenge is how to obtain higher productive yields without covering more area and even trying to use less than the current one. The NDC highlights that, by 2030, the goal is to maintain a reduction in the total area of pasture at an annual rate of $1 \%$, and an increase in pasture with good management at a rate of $1-2 \%$ annually over the baseline trend.

Currently, about 1,000 farms are implementing measures to mitigate and adapt to climate change. By 2022, the goal is for 1,773 farms to not only have reduced their emissions (a cut of 39,000 tons of $\mathrm{CO}_{2} \mathrm{e}$ is expected) and increased their resilience, but also be more profitable economically. By 2034 it is expected to have $70 \%$ of the farms operating under these sustainability criteria. The objective of the Livestock NAMA is to ensure that the farms generate the highest possible economic performance per unit of area, betting on efficiency and sustainability. All this without extending the agricultural frontier, rather trying to recover the forest cover through living fences and wooded pastures (currently there are 20 million trees scattered in the area). In this sense, and according to calculations made by the National Forestry Financing Fund (FONAFIFO) in 2015 when the NAMA was designed, the country has a forestry recovery potential of 620,000 hectares just by combining agricultural activity with trees (CR-MINAE-MAG, 2015).

However, the existing ambiguity about some of the central concepts of the silvopastoral issue in its different modalities and its relationships with climate change, mitigation, adaptation, and low-carbon economy, favors and stimulates the appearance of the so-called "discursive traps" (Rosenfeld, 2004). An example of these discursive traps is the use of phrases such as: "good silvopastoral practices", "silvopastoral lessons learned", "Mixed Systems in Agroforestry for micro-producers", "rotational silvopastoral grazing", "tree grazing pastures", "guidelines for silvopastoral integration". sometimes used in legal or corporate documents: that can cause confusion, with the silvopastoral matter.

The consequences of the use of silvopastoral systems and practices on sectoral policies, strategic plans and territorial organization, such as the initiatives of national actions for mitigation and adaptation (NAMA), cannot be analyzed through optimization equations with given restrictions; but they should be explored and critically revised through indicators numerical as well as qualitative such as: kilograms of milk per hectare, kilograms of meat per hectare, tons of sequestered $\mathrm{C}$ per hectare, reduction of emissions per hectare, which include the participation of the involved sectors (Havlík et al., 2014).

The links between the academic interpretation about silvopastoral production and the interest of the population of small livestock producers are multiple and sometimes divergent. Their immediate 
antecedents turn out to be complex and are rapidly transformed, in the light of the local political and ideological unrest.

SPS are a production choice in the buffering zones of protected or conservation areas, which also favor the preservation of biodiversity and are adjusted to the strategies of the programs of reduction of emissions by deforestation and degradation of forests (REDD+), because they allow to widen the forest cover, produce timber, and contribute to the decrease of emissions.

These systems would allow the reconversion of very little productive extensive livestock production into more productive systems, and the rehabilitation of the areas degraded by extensive livestock production, deforestation, and soil depletion.

Finally, I believe, based on all the arguments consulted, that the SPS play a very important role within the strategy of a low carbon economy in the country and that they are an effective tool to achieve its objectives in the livestock sector. 


\section{REFERENCES}

Abarca Monge, S. (2016). Emisión de gases de efecto invernadero y absorción de carbono en fincas ganaderas. Alcances Tecnológicos.11(1):71-76.

Botero, R; Russo, R.O. (2016). Sistemas silvopastoriles en Mesoamérica para la restauración de aéreas degradadas. En: Restauración funcional del paisaje rural: manual de técnicas. UICN, San José, Costa Rica. pp. 251-342. https://portals.iucn.org/library/sites/library/files/documents/ST-GFE-no.03.pdf

CR-IMN-MAG (Costa Rica-Instituto Meteorológico Nacional-Ministerio de Agricultura y Ganadería). (2019). Inventario Nacional de gases de efecto invernadero y absorción de carbono 2015. Primera Edición. https://cambioclimatico.go.cr/wp-content/uploads/2020/10/NIR-2015-InventarioGEI.pdf

CR-MAG (Costa Rica-Ministerio de Agricultura y Ganadería). (2018). Costa Rica en ruta hacia la descarbonización de la ganadería 2013-2018. San José, CR: Programa Nacional de Ganadería, MAG. http://www.mag.go.cr/bibliotecavirtual/L0111104.PDF

CR-MINAE (Costa Rica-Ministry of Environment and Energy). (2015). Costa Rica's Intended Nationally Determined Contribution (NDC). (Costa Rica-Instituto Meteorológico Nacional-Ministerio de Agricultura y $\quad$ Ganadería).. $\quad$ https://www4.unfccc.int/sites/ndcstaging/PublishedDocuments/Costa\%20Rica\%20First/INDC\%20Costa\%20Rica\%20Version\%202\%200\%20final\%20ENG.pdf

CR-MINAE (Costa Rica-Ministerio de Ambiente y Energía). (2020). Contribución Nacionalmente Determinada 2020. Costa Rica presenta la siguiente información de conformidad con sus responsabilidades bajo los párrafos 24 y 25 de la decisión 1/CP.21 de comunicar o actualizar su Contribución Nacionalmente Determinada (NDC) al 2020. San José, CR: MINAE.

https://www4.unfccc.int/sites/ndcstaging/PublishedDocu-

ments/Costa\%20Rica\%20First/NDC\%20Costa\%20Rica\%202020\%20-\%20Con-

tribuci\% $3 \%$ B3n $\% 20$ Nacionalmente $\% 20$ Determi-

nada\%20de\%20Costa\%20Rica\%202020\%20-\%20Metas\%20titulares.pdf

CR-MINAE-MAG (Costa Rica-Ministerio de Ambiente y Energía-Ministerio de Agricultura y Ganadería). (2015). Estrategia de Ganadería Baja en Carbono. San José, CR: MINAE-MAG.

www.mag.go.cr/bibliotecavirtual/L01-11006.pdf

CR-SEPSA (Costa Rica-Secretaría Ejecutiva de Planificación Sectorial Agropecuaria). (2011). Política de estado para el sector agroalimentario y el desarrollo rural costarricense 2010-2021. San José, C.R.: SEPSA/MAG.

https://www.inder.go.cr/acerca del inder/politicas publicas/documentos/Politica-sector-agro-20102021.pdf

CR-SEPSA (Costa Rica-Secretaría Ejecutiva de Planificación Sectorial Agropecuaria). (2016). Estrategia de Articulación Sectorial Agroambiental y de Cambio Climático. Elaborado por: Franklin Charpantier, Mercedes Flores, Roberto Flores, y Lorena Jiménez. San José, C.R.: SEPSA/MAG.

www.mag.go.cr/bibliotecavirtual/P40-11019.pd f

El Pais (Diario Digital Nuestro País). (2021). Expertos aseguran que ganadería en Costa Rica captura más gases efecto invernadero de los que emite. Elpais.Cr, Nacionales, 2 Febrero, 2021. www.elpais.cr/2021/02/02/expertos-aseguran-que-ganaderia-en-costa-rica-captura-mas-gases-efectoinvernadero-de-los-que-emite/ 
Guerrero, Y.; Gutierrez Solis, J. F.:, Pezo, D.; Prieto Palacios, G.; Roman- Cuesta, R. M.; Rosales Riveiro, K. A.; Rueda Arana, C.; Lucero Romero, R.D.; Sepúlveda L., C. L.; Serrano Basto, G.; Solarte, A.; Woo Poquioma; N. (2019). Mitigación con Sistemas Silvopastoriles en Latinoamérica. Aportes para la incorporación en los sistemas de Medición Reporte y Verificación bajo la CMUNCC. CCAFS Working Paper no. 254. Wageningen, $\quad$ The Netherlands. https://cgspace.cgiar.org/bitstream/handle/10568/100222/FINAL Mitigaci\%C3\%B3n\%20con\%20SSP \%20en\%20LATAM.pdf?sequence $=5 \&$ isAllowed $=\mathrm{y}$

Havlík,P.; Valina, H.; Herrero, M.; Obersteinera, M.; Schmidd, E.; Rufinob, M.C.; Mosniera, A.; Thornton, P.K.; Böttchera, H.; Conantb, R.T.; Franka, S.; Fritza, S.; Fussa, S.; Kraxnera, F.; Notenbaert, vol. 111 (10): 3709-3714. A. (2014). Climate change mitigation through livestock system transitions. PNAS, March 11, 2014. https://www.pnas.org/content/pnas/111/10/3709.full.pdf

Hernández, I.; Milera, M.; Simón, L.; Hernández, D.; Iglesias, J.; Lamela, L.; Toral, O.; Matías, C.; Francisco, G. (2000). Avances en las investigaciones en sistemas silvopastoriles en Cuba. En: Conferencia electrónica de la FAO sobre "Agroforestería para la producción animal en Latinoamérica". http://www.fao.org/ag/aga/agap/frg/agrofor1/hernand4.pdf

Ibrahim, M.; Pezo, D. (2012). Interacciones en sistemas silvopastoriles. In Producción de madera en sistemas agroforestales de Centroamérica. Guillermo Detlefsen y Eduardo Somarriba (eds.). Turrialba: CATIE. https://www.researchgate.net/profile/Arlene-Lopez-Sampson/publication/281235377_Agroforesteria y la produccion de madera/links/55dc2d5708aec156b9b006b7/Agroforesteria-y-la-produccion-de-madera.pdf\#page $=70$

Ibrahim, M. Camero, A.; Camargo, J.C.; Andrade, H.J. (2003). Sistemas Silvopastoriles en América Central: Experiencias de CATIE. http://www.biopasos.com/biblioteca/sistemas_silvopastoriles_en_Ame$\underline{\text { rica Central experi.pdf }}$

Iglesias, J. M. et al. (2011). Diseños agrosilvopastoriles en el contexto de desarrollo de una ganadería sustentable. Apuntes para el conocimiento. Pastos y Forrajes, 34(3): 241-258.

Pezo, D. (2016). Estrategia regional para la intensificación sostenible de la ganadería, dentro del contexto de la adaptación/mitigación al cambio climático y políticas asociadas. San José, Costa Rica: IICA. 72 p.

Pezo, D; Muschler, R; Tobar, D; Pulido, A. 2018. Innovaciones para la adaptación al cambio climático en los sistemas agrícolas y ganaderos de América Latina y el Caribe. Turrialba, Costa Rica: CATIE. 325 p. (Informe de Consultoría FONTAGRO).

Pezo, D.; Ríos, N.; Ibrahim, M.; Gómez, M. (2018). Silvopastoral systems for intensifying cattle production and enhancing forest cover: The Case of Costa Rica. Program on Forests (PROFOR). Washington DC: The World Bank. https://www.profor.info/sites/profor.info/files/Silvopastoral\%20systems_Case\%20Study_LEAVES_2018.pdf

Rosenfeld, E. (2004). Medio ambiente y calidad de vida. ¿Desarrollo sustentable o trampa discursiva? en Cuenya, B., Fidel, C. y Herzer, H., Fragmentos sociales: Problemas urbanos de la Argentina. Buenos Aires: Siglo XXI Editores, pp. 251-264. 2004.

Russo, R.O. (1996). Agrosilvopastoral systems: a practical approach to sustainable agriculture. J. Sustainable Agriculture 7(4): 5-17. 1996. 
Russo, R.O. (2015). Reflexiones sobre los sistemas silvopastoriles. Pastos y Forrajes, Vol. 38, No. 2, $157-161$.

Suber, M.; Gutiérrez Beltrán, N.; Torres, C. F.; Turriago, J. D.; Arango, J.; Banegas, N.R.; Berndt, A.; Bidó, D. I. M.; Burghi, V.; Cárdenas B., D. A.; Cañanda, P.; Canu, F. A.; Chacón, A. R.; Chacón Navarro, M.; Chará, J.; Diaz, L.; Huamán Fuertes, E.; Espinoza Bran, J.E.; Girón Muñoz, P. R.; 